Taking these cases as representative of at least an important tendency in the American common law, there is a strong likelihood that the defendants would have been liable had they been tried in an American court. ${ }^{28}$ For the agent has been warned in the American decisions that even when simply executing his principal's commands, his legal status does not secure him from all attacks. The view in England being different, the problem of evaluation is provoked.

The English position accords well with the recent legislation, reducing generally the duty to the trust estate of those dealing with a trustee. Under the Uniform Fiduciaries Act, ${ }^{29}$ a banker, a transfer agent for stocks, or one paying money for goods or land to a trustee, is liable only when he knew he was taking part in a breach, made a personal gain from the breach, or had actual knowledge of facts which made it an act of bad faith for him to act as he did. ${ }^{30}$ Apparently this legislation was stimulated by the necessity for facile administration of trust estates. ${ }^{3 \mathrm{I}}$ If the importance of security in transactions is conceded to be greater than protection of cestuis que trust, there seems to be no reasonable basis for withholding from an agent of a trustee the protection supplied by the Uniform Fiduciaries Act to other persons dealing with a trustee. Indeed, the strong reasons ${ }^{32}$ underlying the conceptual immunity of an agent who acts within his authority afford both provocation and justification for extending the statutory protection to agents of trustees.

\title{
TORT LIABLITY OF A CHARITABLE CORPORATION
}

The plaintiff, a paying patron at a ball game sponsored by the defendant, was injured when a row of bleachers collapsed. Against the defendant's plea that it was immune from tort liability as a charitable corporation, the plaintiff

agent. But since this court expressly declined to overrule Leake v. Watson, 58 Conn. 332,20 Atl. 343 ( 1890 ) (brokers held liable because they had actual knowledge that they were dealing with fiduciaries, though they did not know the terms of the trusts), it would seem that the court admitted the general rule of liability should follow when the agent has actual knowledge that trust funds are involved. The view of notice adopted by the Connecticut court in Titcomb v. Richter is approved by the California court in Northwestern Portland Cement Co.v. Atlantic Portland Cement Co., I74 Cal. 308, 3 II, I63 Pac. 47, 49 (IgI7), but is adversely criticized in 29 Harv. L. Rev. 232 (Igr5); Shaw v. Spencer, roo Mass. 382, 393-94 (r868). For a general discussion of this question, see 4 Bogert, Trusts and Trustees $\$ \$ 894,902$ (1935)

${ }^{28}$ Unquestionably, the defendants were aware that their principal was a trustee; again, there is no doubt of their knowledge that trust funds were involved. Not only had the defendants themselves drawn up the declaration of a trust, but they had it at all times in their safe. Williams-Ashman v. Price and Williams, [I942] I Ch. 219, 221.
${ }^{29} 9$ U.L.A. 297 (1942).
$3^{30}$ Notes $12-16$ supra.
${ }^{2}$ Note Ir supra.

${ }^{32}$ Consider this statement made by Lord Selbourne in Barnes v. Addy, L.R. 9 Ch. App. 244, 252 (I874): "If those principles were disregarded [viz., that an agent is liable only when he has profited by or has acted despite actual knowledge of the breach], I know not how anyone could, in transactions admitting of doubt as to the view which a Court of Equity might take of them, safely discharge the office of solicitor, of banker, or of agent of any sort to trustees." 
argued that immunity should not be extended to an occasion for which there was charged an entrance fee that was higher than it would appear necessary to cover expenses, and that immunity, should not be granted to a charity which had protected its funds by liability insurance. Trial in the circuit court resulted in verdict and judgment for the plaintiff. Held: Reversed. A corporation which under its charter is to use all its income for the furtherance of a charitable purpose is immune from tort liability even though it charges a fee for admission to the activity at which the tort occurred; to inform the jury, directly or indirectly, that a defendant is insured against liability is improper. Myers v. Young Men's Christian Ass'n. ${ }^{\mathrm{I}}$

The Illinois courts have consistently insulated charitable corporations from tort liability by adhering strictly to the view that the property acquired by a charitable institution constitutes a trust fund which is not to be diverted from its beneficent purpose to satisfy judgments resulting from the negligent acts of its employees. ${ }^{2}$ Actually, as in the instant case, most charities are corporations with complete ownership of their assets. Applied to such cases, the trust fund doctrine appears as a judicial expression of policy notions favoring the protection of charities. ${ }^{3}$ In Illinois, while most attempts to narrow or eliminate the rule of tort immunity have failed, ${ }^{4}$ some success was achieved at the trial court stage in two recent cases. In one case, recovery was granted where the injured party was a stranger to the charitable corporation. ${ }^{5}$ In the other, the court refused to grant immunity to a charitable corporation which was protected by liability insurance, as recovery would not lead to a reduction of the charitable assets. ${ }^{6}$ However, the decision in the former case never reached an appellate court; $^{7}$ and as to the latter situation, the Appellate Court has adopted a contrary view in the instant case. While the Mllinois courts have for the most part

${ }^{x} 44$ N.E. (2d) 755 (IIl. App. 1942).

2 Parks v. Northwestern University, 218 III. 38I, 75 N.E. 99I (I905); Hogan v. Chicago Iying-In Hospital, 335 Ill. 42, I66 N.E. 46I (I929).

32 Bogert, Trusts and Trustees $\S 4$ or (1935).

4 A note in 6 Univ. Chi. L.Rev. 518 (I939) discussing the case of Maretick v. South Chicago Community Hospital, 297 Ill. App. 488, I7 N.E. (2d) IOI2 (1938), contains an analysis of the Illinois cases. There the note writer indicated that except for a dictum in the case of Olander v. Johnson, 258 Ill. App. 89 (I930), where it was stated that a charitable corporation might be liable if it failed to use due care in the selection of its servants, there has been no deviation by the Illinois courts from the rule of tort immunity.

5 George Weil Cartage Company v. Sisters of the Foly Family of Nazareth Corporation, Cir. Ct. of Cook Co. (I939) (cited in 20 Chicago Bar Record I $_{4}$ (I939)).

${ }^{6}$ Shaleen v. The Newberry Library, Superior Ct. Cook Co. (1942) (cited in Survey of Illinois Law for the Year I941-I942, 2I Chicago-Kent. L. Rev. I, 8 n. 45 (r942)).

7 In Johnston v. City of Chicago, 258 Ill. 494, ror N.E. 960 (1913), the city was liable for the negligence of an employee of the public library board when the employee, who was driving an automobile, collided with a third person. The theory of the court was that a municipal corporation should discharge ministerial acts without negligence. The court gave no indication as to its decision had the defendant been a charitable rather than a municipal corporation. 
adhered rigorously to the rule of tort immunity, the charitable corporation is not equally immune from actions for breach of contract. ${ }^{8}$ Thus, recovery of contract damages will be permitted although it may result in a diversion of the charitable funds. In the instant case, the plaintiff, by virtue of having paid admission, was in contractual relationship with the defendant. It might well be argued that the defendant had contracted to provide the plaintiff with safe seating arrangements, and, in failing to do so, was liable for contractual damages. However, in Illinois, recovery has been denied for breach of contract if it resulted in a personal injury where the gist of the action was carelessness by some servant.9

As to the theoretical foundations of the immunity from tort liability, other courts have resorted to various doctrines in addition to the trust fund doctrine, which has served as a basis for the decisions of the Illinois courts. These doctrines include, I) non-applicability to a charitable institution of the doctrine of respondeat superior; 2) implied waiver of liability on the part of a beneficiary of a charitable institution; or, simply, 3) public policy in favor of such institutions, which seems to be the frankest statement of the rationale of the decisions. In most jurisdictions, however, the immunity is not complete. Controversy is provoked by the question of whether or not exceptions should be made in favor of one or more groups, viz., strangers to the charity, paying beneficiaries, or non-paying beneficiaries, and also by the question of whether or not the charitable institution should be charged with the acts of some particular type of agents or employees. ${ }^{10}$ The decisions, the various doctrines, and the criticisms have been collected and discussed recently in a scholarly opinion by Associate Justice Rutledge of the Court of Appeals of the District of Columbia (now of the United States Supreme Court), who states convincingly that continued protection of charitable corporations from tort liability is justified by neither legal theory nor public policy. Ix

Ideally, the function of tort law is to provide the machinery for efficient distribution of loss. Courts concerned themselves primarily with notions of "fault," and the evolution of the modern law of torts has proceeded along these lines. ${ }^{\mathrm{x} 2}$ But courts have also shown a tendency to impose liability upon certain

${ }^{8}$ Armstrong v. Wesley Hospital, x70 Ill. App. 8I (I9r2); Ward v. St. Vincent Hospital, 39 App. Div. 624, 57 N.Y. Supp. 784 (I899).

9 Wattman v. St. Luke's Hospital Ass'n 3 I4 Ill. App. 244, 4r N.E. (2d) 3 I4 (I942). But see Armstrong v. Wesley Hospital, I70 Ill. App. 8r (I9I2).

${ }^{20}$ Thus, for example, a beneficiary-particularly a non-paying one-is frequently denied recovery where the negligent act was committed by a servant of the charity. On the other hand, a stranger to the charity is often permitted to recover under similar circumstances.

rs President and Directors of Georgetown College v. Hughes, r3० F. (2d) 8ro (App. D. C. I942).

${ }^{12}$ See Kendall v. Brown, 60 Mass. 250 (I850). It is generally recognized that so long as the "fault" notion continues to constitute the principal basis for liability in tort, risks and losses will frequently fail to be distributed satisfactorily. But while a relaxation of the fault 
entrepreneurs who have merely created the risk and are deemed to be best able to sustain or distribute the loss..$^{{ }^{3}}$ Extending the rule of respondeat superior, courts have frequently thwarted the efforts of employers to insulate themselves from tort liability by employing an independent contractor, ${ }^{14}$ or by acting through a subsidiary corporation. ${ }^{15}$ The legislatures, in the workmen's compensation acts, reflect the same desire to distribute loss effectively. Dissatisfied with the frequent irresponsibility of the individual motorist, moreover, they have provided in some instances for compulsory automobile insurance and in others for proof of financial responsibility, ${ }^{x}$ thereby giving adventitious emphasis to the necessity for a broader basis of loss distribution. A judicial expression of the same desire is found in the family car doctrine. Even the stronghold of government tort immunity has been severely attacked, ${ }^{17}$ and numerous inroads have been made. ${ }^{x}$ These trends indicate that both courts and legislatures are concerned about the one who has suffered a loss, and that immunity from tort liability ought to be regarded as justified only in the face of strongly compelling factors.

The anomalous position of the remediless beneficiary of a charity is particularly difficult to justify. Associate Justice Rutledge, in criticizing the retention of immunity in the case of the non-paying beneficiary, properly stated: "He, least of all, is able to bear the burden. More than all others, he has no choice. $\mathrm{He}$ is the last person the donor would wish to go without indemnity." ${ }_{99}$ The dictates of social policy may have at one time required an occasional individual to suffer so that the public in general might enjoy undiminished the bequests to private philanthropies. Fear that donors might be deterred from making

notion may well constitute an ultimate goal, the existing tort machinery should be refined to ease the burden of individual loss in the interim. Compare, James, Contribution among Joint Tort Feasors: A Pragmatic Criticism, 54 Harv. I. Rev. II56 (I94I), with Gregory, Contribution among Joint Tort Feasors: A Defense, 54 Harv. L. Rev. Ir70 (I94I).

${ }^{x_{3}}$ See Feezer, Capacity to Bear Loss as a Factor in the Decision of Certain Types of Tort Cases, 78 U. of Pa. L. Rev. 805 (1930); Loss-Shifting and Quasi-Negligence: A New Interpretation of the Palsgraf Case, 8 Univ. Chi. L. Rev. 729 (I94r).

${ }^{14}$ See Steffen, Independent Contractor and the Good Life, 2 Univ. Chi. L. Rev. 50r(1935).

Is Costan v. Manila Electric Co., 24 F. (2d) ${ }_{3} 83$ (C.C.A. 2 d r928); Wallace v. Tulsa Yellow Cab Co., I78 Okla. 15, 6x P. (2d) 645 ( 1936 ).

166 Blashfield, Cyclopedia of Automobile Law and Practice $\$ \S 3851-58$ (I935); Engel, Discharge in Bankruptcy as "Satisfaction" under Automobile Responsibility Statutes, 5 U. of Pitt. L. Rev. 26, 28 n. 10 (1939).

${ }^{17}$ Borchard, Government Liability in Tort, 34 Yale L. J. I, I 29, 229 (1924-25); Borchard, The Federal Torts Claims Bill, I Univ. Chi. I. Rev. I (1933).

${ }^{8}$ Keifer \& Keifer v. RFC., 306 U.S. 38I (1939). As to proposed federal legislation, see Armstrong and Cokcrill, The Federal. Torts Claims Bill, 9 Law \& Contemp. Prob. 327 (I942). The proposed bill has now been committed to the Committee of the Whole House on the State of the Union. S. 222r, 77th Cong. 2d Sess. (I942).

${ }^{19}$ President and Directors of Georgetown College v. Hughes, r30 F. (2d) 8ro, 827 (App. D.C. I942). 
charitable bequests, or that bequests once made would be dissipated in litigation, was the rationale behind most of these decisions. ${ }^{20}$

Now, however, many of the functions formerly performed exclusively by charities are supplemented by government-supported institutions. Furthermore, charitable corporations of today are conducted more nearly along the lines of private enterprises than were their earlier counterparts. Often, indeed, the organization is to a considerable extent supported by paying patrons, as is the defendant corporation in the instant case. Again, liability insurance is available as an effective medium for the distribution of loss; the charitable corporation is thus in a position to pass on the premium, at least in part, to its paying beneficiaries. In the instant case, the plaintiff's attempt to show that the corporation would be indemnified by liability insurance presented the court with the choice of either relaxing the rule of tort immunity where the charitable fund was protected by insurance, ${ }^{2 x}$ and thereby making it advantageous for charitable corporations not to insure, or applying the rule of full tort immunity without regard for the fact that presence of insurance had rendered this protection unnecessary. As long as the present rule of immunity prevails, it seems a sheer waste of money for a charitable corporation to purchase protection. ${ }^{22}$

The abolition of tort immunity would still leave charities in a preferred position when compared with private corporations. For example, the growth of charities is fostered by various exceptions to the rule against remoteness and to the rules against restraints on alienation and accumulations. ${ }^{23}$ Moreover, in their taxation policies, legislatures favorably regard gifts and legacies to charities, as well as the property owned by charities. ${ }^{24}$ The costs of these advan-

${ }^{20}$ Parks v. Northwestern University, 218 Ill. 38r, 75 N.E. 99r (r905). But this policy notion has not been extended to the gratuitous acts of private individuals, who are held to the same standard of care as a person performing the act for consideration. Harper, Torts $\$ 8 I$ (r933).

${ }^{2 x}$ The court in the instant case expressly refused to follow the case of $\mathrm{O}^{\prime} \mathrm{Connor} v$. Boulder Colorado Sanitarium Ass'n, ro5 Colo. 259, 96 P. (2d) 835 (I935), noted in 7 Univ. Chi. L. Rev. 567 (I940), where it was held that if the charitable fund were protected from depletion by insurance there was no immunity under the trust fund theory against an action sounding in tort. The Illinois court bassed its refusal on the ground that the jury should resolve questions of liability apart from a consideration of the presence in the background of an insurance company. Actually, the plaintiff merely sought the abolition of a rule of immunity which precluded any consideration of liability. That this clearly would not determine liability is indicated in the $O^{\prime}$ Connor case, where the plaintiff on the next round failed to recover damages by failing to prove negligence. O'Connor v. Boulder Colorado Sanitarium Ass'n, I07 Colo. 290, III P. (2d) 633 (I94I).

${ }_{22} 3$ Scott, Trusts and Trustees $\S 402$ (1939).

232 Bogert, Trusts and Trustees $\$ \S 349,350,353$ (I935). Under a statute similar to the Thellusson Act, it appears that in Illinois a charitable corporation will be treated the same as a private one so far as the rule against accumulations is concerned. IIl. Rev. Stat. (I94I) c. $30, \S$ I53.

${ }^{24} \mathrm{~A}$ recent judicial discussion of the exemption of charitable corporations from taxation can be found in International Reform Fed. v. Dist. Unemployment Comp. Bd., I3 I F. (2d) 337 (App. D.C. 1942). 
tages are spread over the entire community, while the rule of tort immunity places the loss squarely on a single individual. Clearly, charitable corporations should, as do private corporations, bear the cost of their tortious acts, and the rule of tort immunity which leaves an undeserved loss on an unfortunate individual should be abolished.

\section{SECONDARY BOYCOTT UNDER THE SHERMAN ACT AND NORRIS-LAGUARDIA ACT}

Local 306 of the Motion Picture Machine Operators' Union ${ }^{x}$ threatened to strike Loew's New York distributing center and, through its national union, to strike Loew's production plant on the west coast, unless Loew's agreed to supply films only to Manhattan theatres unionized by Local 306. Similar demands were to be made on seven other leading distributors, ${ }^{2}$ thus threatening a virtual suspension of the entire film industry, if this agreement were not signed. Loew's sought an injunction and a declaratory judgment outlawing the requested agreement under the Sherman Act. Held, relief granted as requested. Loew's, Inc. v. Basson. ${ }^{3}$

Despite the court's holding to the contrary, it seems clear that there was a labor dispute between the parties under the Norris-LaGuardia Act ${ }^{4}$ and that therefore the injunction should not have issued. The court stated that the demands of the union bore "no reasonable relation to wages, hours, health, safety, working conditions, or the right of collective bargaining," and that they were not directed toward any "normal" or "lawful" labor objective..$^{5}$ But in so reasoning the court obviously relied too much on the fact that the union has no quarrel with the company concerning its own employment standards and neglected the importance to the union of the economic support which the company lends to non-organized or rival-organized theatres by continuing its present contracts. Furthermore, the court, in saying that the objective must be "normal" and "lawful," is reading a qualification into the statute. State courts have sometimes done this with their "little Norris-LaGuardia Acts," but it is far

I An affiliate of the International Alliance of Theatrical and Stage Employees, A.F.L.

2 Columbia Pictures Corp., Paramount Pictures, Inc., R.K.O. Radio Pictures, Inc., Twentieth Century-Fox Film Corp., United Artists Corp., Universal Pictures Co., Inc., and Warner Bros. Pictures, Inc.

${ }^{3} 46$ F. Supp. 66 (N.Y. I942).

${ }_{4}$ "The term 'labor dispute' includes any controversy concerning terms or conditions of employment, or concerning the association or representation of persons in negotiating, fixing, maintaining, changing, or seeking to arrange employment ..." § I3 (c), 47 Stat. 70 (I932), 29 U.S.C.A. $\& \times x_{3}$ (c) ( 1942$)$.

5 Loew's, Inc. v. Basson, 46 F. Supp. 66, 7 I (N.Y. I942).

${ }^{6}$ This tendency has been especially marked in New York. American Guild of Musical Artists, Inc. v. Petrillo, 286 N.Y. 226, 36 N.E. (2d) I23 (I94r); Opera on Tour, Inc. v. Weber, 285 N.Y. 348,34 N.E. (2d) 349 (I94 I), noted in 9 Univ. Chi. L. Rev. r7o (r94I). 